\title{
Assessment of water-saving equipment to support the urban management of water
}

\section{Avaliação de equipamentos economizadores como suporte ao gerenciamento urbano de água}

\author{
Juliana Karla da Silva ${ }^{1}$, Luiz Gustavo Costa Ferreira Nunes ${ }^{1}$, Anna Elis Paz Soares ${ }^{1}$ and Simone Rosa da Silva ${ }^{1}$ \\ ${ }^{1}$ Universidade de Pernambuco, Recife, PE, Brazil \\ E-mails: julianaks@gmail.com (JKS), 1.gustavo.nunes@hotmail.com (LGCFN), anna_elispaz@hotmail.com (AEPS), simonerosa@poli.br (SRS)
}

\begin{abstract}
The objective of this study was to analyze the environmental and economic impacts of the implementation of water-saving equipment in residences in the municipality of Caruaru-PE as a measure of water conservation and mitigation of the drought effects that have been devastating the region along the past five years. For this purpose, eight neighborhoods were selected and their populations were estimated along the years of 2015 and 2035. Subsequently, the water consumption per capita, water volumes consumed with the use of conventional sanitary equipment and with the use of water-saving equipment were calculated, obtaining the volume of water saved. For the estimates of cost for the services and material required for the installation of water-saving equipment, tables of price compositions for budgets were consulted and adapted. The results demonstrated that it is possible to save up to $40 \%$ of consumed water only with the implementation of water-saving equipment, with a mean return time of six and a half years. Therefore, it is possible to understand that the use of water-saving equipment represents an important instrument of water management.
\end{abstract}

Keywords: Water management; Water-saving equipment; Water conservation.

\section{RESUMO}

O presente estudo objetivou verificar os impactos ambientais e econômicos da implantação de aparelhos economizadores de água em residências do município de Caruaru-PE, como medida de conservação de água e mitigação dos efeitos da seca que vem assolando a região há cinco anos. Para tanto, foram selecionados alguns bairros e estimadas as populações dos anos de 2015 e 2035. Posteriormente, foram determinados os consumos per capita de água, os volumes médios de água consumidos com o uso de aparelhos hidrossanitários convencionais e com o uso de aparelhos economizadores, obtendo-se os volumes economizados. Foram realizadas análises financeiras, a partir da estimativa do investimento previsto, ou seja, aquisição dos equipamentos e custo dos serviços atrelados a implantação destes. Para essas estimativas de custo, tabelas de composições de preços para orçamento foram consultadas e adaptadas. Os resultados mostraram que é possível economizar até 40\% da água consumida, apenas com a implantação de aparelhos economizadores, com tempo de retorno médio de seis anos e meio. Desta forma, é possível perceber que o uso dos equipamentos economizadores representa um importante instrumento de gestão hídrica.

Palavras-chave: Gestão hídrica; Aparelhos economizadores; Conservação de água. 


\section{INTRODUCTION}

Since 2012, the Northeast of Brazil is suffering a severe drought, regarded as the longest over the past 50 years, according to Abicalil (2014); as a consequence, many of the reservoirs that supply the municipalities are collapsing, which means it no longer offers the conditions for capturing water for human consumption. Lacerda (2015) established long-term rainfall tendencies for the state of Pernambuco through indices of detection of climate changes. According to the author, the results indicated tendencies of maximum temperature increase and annual mean rainfall reduction in all of the stations inspected in the research.

As an emergency measure for drought situations, water and sanitation companies tend to withdraw water from other sources, increasingly far from the localities to be supplied. The adoption of rationing regarding the use of water, reduction of consumption and capture of rainwater in residences may represent adequate alternatives to mitigate the issue of water shortage (LEUCK, 2008; IMTEAZ et al., 2012; HAQUE et al., 2015; RATH et al., 2016; SINGH; JHA; CHOWDAYRY, 2016).

In this context, many regions worldwide developed water conservation plans presenting measures such as the substitution of sanitary equipment with water-saving equipment, that is, equipment that allow an optimized use of water, consuming the minimum volume possible for the aimed activity, a context in which the cases of Australia, California, Waterloo, and Barcelona can be highlighted.

Australia, for example, between the years of 2000 and 2009 , adopted actions that resulted in a reduction of $35 \%$ in water consumption per capita due to three factors: adoption of restriction regarding the outdoor use of water, incentive to the use of water-saving equipment (flush valves), and alterations in the price of water (CAHILL; LUND, 2012).

California has been facing since the last decade intensive drought periods, culminating in a state of emergency in 2009 and 2014. In response to the drought conditions, the water agencies implemented many water-saving programs and voluntary measures as well as stricter plans including water bill rise. The voluntary restrictions, when there are no penalties linked to failure to comply with the proposed measures, applied along the period from 2007 to 2008 did not contribute to the reduction of water consumption regarding the domestic use. From the mandatory restrictions implemented in 2009 with the application of fines, more significant results began to appear. Between July and August 2007, the mean water consumption in the city was $140 \mathrm{~m}^{3} /$ residence, while along the period from May to June 2010, the mean consumption dropped to $94 \mathrm{~m}^{3}$ / residence (MINI; HOGUE; PINCETL, 2015).

Waterloo, Canada, has developed many programs in favor of water conservation, including the "Toilet Replacement Program - TRP”. Implemented in 1994, it aims at encouraging the substitution of residential sanitary systems which consume from 18 to 30 liters of water/flushing with a sanitary system that consumes six liters/flushing. Along with incentives to water reduction in the domestic use, the remaining uses of water have also been provided with encouragement, obtaining a reduction of $8,504 \mathrm{~m}^{3} /$ day from 2007 to 2011 , overcoming in $42 \%$ the expected for the year of $2011\left(5,988 \mathrm{~m}^{3} /\right.$ day $)$ and even the expected for 2015 (8,146 m³) (BRAGA; RIBEIRO, 2001; REGION OF WATERLOO WATER SERVICES, 2014).

Over the last decade, Barcelona has suffered with a severe drought during which a law was instituted to promote extraordinary, emergency measures to rationalize the use of water throughout the territory of Catalonia in order to assure human subsistence, including measures of control water supply and demand, containing the following: restrictions to the outdoor use of water, distribution of technological devices, such as aerators, in addition to campaigns of awareness. The average of water saving along the drought period was of $14.5 \%$; furthermore, the Catalan Water Agency states that even after the drought period, the region maintained water saving of approximately five percent (EEA, 2015).

In Brazil, the strategic measures used by the State of São Paulo to address the consequences of the water crisis that began in 2014 are detached. Among them: a bonus for clients who could reduce water consumption in their homes by $30 \%$; media campaigns; support to environmental education in the field of water economy; besides stimulating the reuse of water (SABESP, 2015).

According to SUDENE (2013), about $70 \%$ of the municipalities of northeastern Brazil are located in a region called drought polygon, where they are characterized by areas subject to water shortages. Within this scenario, the municipality of Caruaru, located in the Agreste region of Pernambuco, has already been experiencing the consequences of a drought. In the year 2014, for example, during nine months it rained in the municipality quantities below the average of historical precipitations (1960/2009). The average monthly precipitation presented in this historical series for the months of January, March and December is $47.58 \mathrm{~mm}$, $94.24 \mathrm{~mm}$ and $28.20 \mathrm{~mm}$, respectively. While in 2014 , for the same months, the average monthly precipitation values were $10.6 \mathrm{~mm}$, $51.8 \mathrm{~mm}$ and $18.40 \mathrm{~mm}$; in the second semester of 2015, one of its dams, responsible for over $50 \%$ of its water supply, collapsed. Caruaru, in addition to being the municipality with the highest population in the Agreste, has great importance for the economy of the state for being part of the textile hub in the region, along with Toritama and Santa Cruz do Capibaribe.

Therefore, considering the constant water shortage situation in Pernambuco, the difficulties to supply the population of the Agreste (Savannah) in the state as well as the importance of further studies to mitigate the consequences of the drought through water conservation, the municipality of Caruaru was selected to develop this paper. Specifically, this research aimed at verifying the impact of implementing water-saving equipment in residences of the municipality of Caruaru, considering three hypothetical scenarios of substitution of conventional sanitary equipment with water-saving equipment.

\section{METHODOLOGY}

\section{Selection of the study area}

The municipality of Caruaru is located in the Ipojuca River basin, with an area of $920.611 \mathrm{~km}^{2}$ and, according to the 2010 demographic census, a population of 314,912 inhabitants (IBGE, 2010). The map of Figure 1 shows the geographical location of Caruaru. 


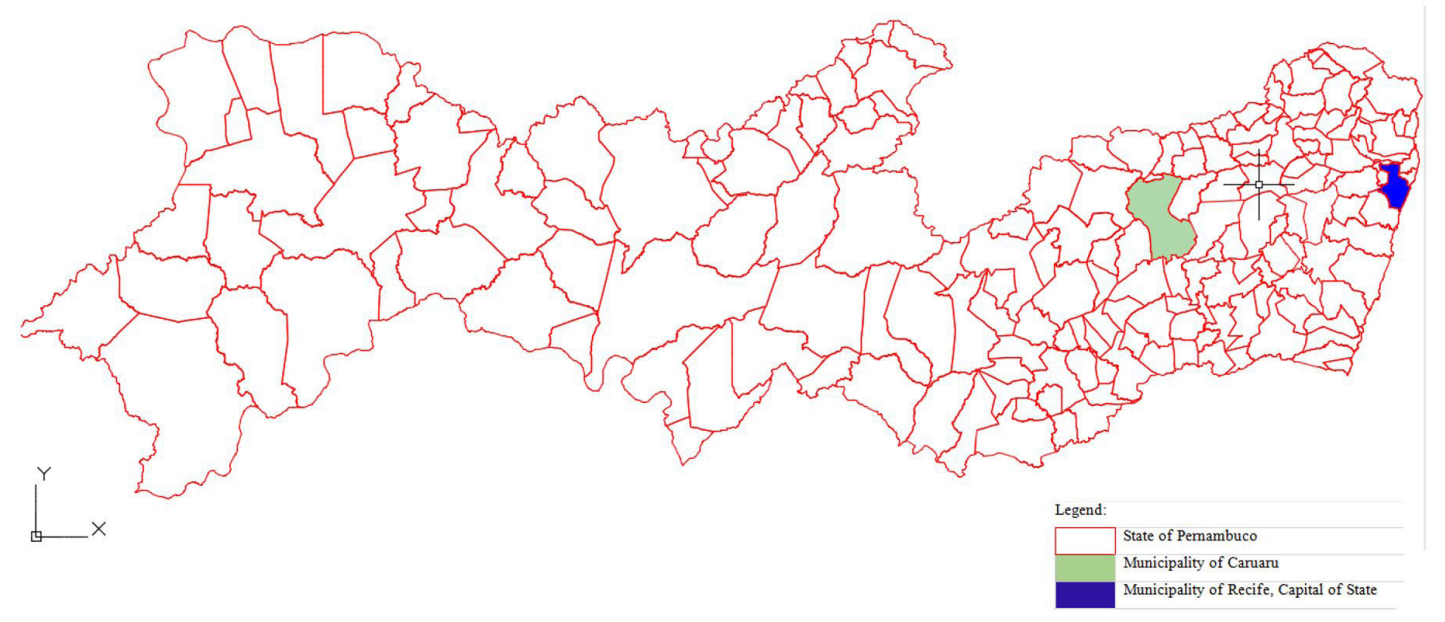

Figure 1. Location of the municipality of Caruaru.

Source: Data provided by the local concessionaire.

To refine the study area, eight neighborhoods with differentiated characteristics were selected, in order to represent the impact of the research on different consumer audiences. The following criteria were considered in the selection of neighborhoods: predominance of popular dwellings, of medium and high constructive standard; more populated and less populous neighborhoods; as well as neighborhoods with peculiar characteristics, as a highlight in tourism or commerce in relation to others. Also, this selection was based on the availability of data provided by the Companbia Pernambucana de Saneamento - COMPESA (Pernambuco Water and Sanitation Company). Thus, eight out of the 23 neighborhood existing in the city of Caruaru were selected to be part of the study.

The information required for the analysis of the areas were obtained through researches on websites of Bodies of the municipality and the Instituto Brasileiro de Geografia e Estatística - IBGE (2010), in addition to the data provided by COMPESA.

\section{Characterization of water consumption}

The first step to establish which actions would be more relevant for water management is to know the consumption records for the residences in the region. For the purposes of this study, the local water company made available the volume of water consumption measured by neighborhood, month by month, and the number of residences of each neighborhood, in the years 2010 to 2015 . This study concentrated on the data referent to the year of 2015, when it occurred, in the second semester, the pre-collapse of the water sources in the municipality of Caruaru. Furthermore, it was carried out a demand forecast considering a timeline of twenty years, that is, in the year of 2035 .

\section{Water consumption indicator}

The study to establish the Consumption per capita of water (CpA - in Portuguese Consumo per capita de água) for each area was carried out by using the data referent to the measured volume consumed and saving values (residences) measures, considering an amount of residents per house of 3.3, according to the Database of the State (BDE), as in Equation 1.

$\mathbf{C p A}=\frac{\left(\frac{\text { Measured volume consumed }}{\text { amount of saving values measured }}\right)}{3.3 / 30} \mathrm{~m}^{3 / \text { person } / \text { month }}$

\section{Population projection}

In order to calculate the population, since IBGE provides only the populations until the year of 2010, it was necessary to elaborate a study to estimate the populations regarding the years of 2015 and 2035 .

In order to do that, the method used by IBGE (2010), the geometric progression, was employed, in which it is primarily established the growth rate, according to Equation 2:

$$
R=t_{n}-t_{0} \sqrt{\frac{P_{n}}{P_{o}}}
$$

Where:

R: Ratio of growth;

$\mathrm{P}_{\mathrm{n}}$ : Population in the last census;

$\mathrm{P}_{\mathrm{o}}$ : Population in the previous census;

$\mathrm{t}_{\mathrm{n}}$ : Year of the last census;

$t_{0}$ : Year of the previous census.

After the establishment of the ratio of growth, it is established the rate of growth, according to Equation 3:

$$
\mathrm{T}=(\mathrm{R}-1) \cdot 100
$$

Where:

T: Rate of growth (\%)

('T' from Portuguese 'taxa', which means rate)

Therefore, searching for the population data for Caruaru regarding Censuses for the years of 1991, 2000, and 2010, it was established the mean rate of growth of the municipality. 
The rate found ( $\%$ ) was used in the calculation to determine the population estimated by neighborhood in the years of 2015 and 2035, according to Equation 4.

$$
P=P_{i} \cdot T^{t-t i}
$$

Where:

P: Population of the project;

$\mathrm{P}_{\mathrm{i}}$ : Initial population considered;

t: year of the scope of the project

$\mathrm{t}_{\mathrm{i}}$ : year corresponding to the initial population

T: rate of growth

\section{Characterization of the suggested scenarios}

For the simulations, three scenarios were suggested, considering the investment/costs and reduction in water consumption related to each one of them. Scenario 1 is considered of great impact, scenario 2 has a medium impact, and scenario 3 presents a low impact, according to illustration in Chart 1.

Scenario 1 encompasses the installation of water-saving equipment with a more advanced technology which, according to manufacturers, offers higher saving percentage. Scenario 2 is a mixture of more advanced equipment with simpler equipment. For the third scenario, equipment of less advanced technology are used. Even though it seems obvious the use of more advanced equipment since they have higher water saving percentage, the costs related to them may impair their implementation. That is the reason why the remaining scenarios were considered. To do so, the volumes of water to be saved from the implementation of the suggested measures were quantified. It is worth emphasizing that it was considered one restroom per house since, according to IBGE (2010), 69.9\% of the residences in Pernambuco have only one restroom. It was also considered that the restroom contains a toilet bowl, sink, and shower.

\section{Calculation of the costs related to the simulated scenarios}

For the elaboration of the estimates of costs regarding the services required for the implementation of the water-saving equipment suggested in this paper, the Tables of Price Compositions for Budget - TCPO 14 (from Portuguese Tabelas de Composições de Preços para Orçamento) (PINI, 2013) were consulted as basis. However, since there are no compositions encompassing the use of water-saving equipment, it was necessary to adapt them. In order to estimate the values of the pieces, price quotations in the month of November 2016 were carried out. For the values of the services, it was used the table from the National System of Research of Costs and Indices of Construction Industry - SINAPI (from Portuguese Sistema Nacional de Pesquisa de Custos e Índices da Construção Civil (CEF, 2016). For the definition of the time required to assemble the equipment, the manufacturers were consulted; this information is important to define the costs referent to the services.

\section{Methodology to establish the index of water consumption reduction and investment return for the domestic category}

With the values of consumption per capita established and the studies on the population carried out, the expenses of water in $\mathrm{m}^{3} /$ month could be estimated. The water consumption for each equipment was calculated according to Equation 5, adapted from Guedes, Ribeiro and Vieira (2014).

\section{$C A C i=D C A i \times C M R$}

Where:

$\mathrm{CACi}=$ mean monthly consumption of conventional equipment $\mathrm{i}\left(\mathrm{m}^{3} / \mathrm{month}\right)$;

DCA = distribution of water consumption per sanitary equipment $\mathrm{i}$; $\mathrm{CMR}=$ mean monthly consumption for each area of Caruaru ( $\mathrm{m}^{3} /$ month).

Through Equation 6, the water consumption for each water-saving equipment was established.

$\boldsymbol{C A P i}=(1-\mathrm{Fr}) \times \boldsymbol{C A C i}$

Where:

$\mathrm{CAPi}=$ monthly consumption with the implementation of water-saving equipment $\left(\mathrm{m}^{3} /\right.$ month);

$\mathrm{Fr}=$ factor of reduction of water consumption per sanitary equipment (data provided by the manufacturer representing the ratio between the flow of water-saving equipment and the conventional one. Shown in Table 1);

$\mathrm{CACi}=$ mean monthly consumption of the conventional equipment $\mathrm{i}\left(\mathrm{m}^{3} / \mathrm{month}\right)$.

In order to obtain the saving of water, Equation 7 was adopted:

$E D A i=C A C i-C A P i$

Chart 1. Scenarios suggested for water-saving assessment.

\begin{tabular}{|c|c|c|c|c|c|}
\hline \multicolumn{2}{|c|}{} & \multicolumn{5}{|c|}{ EQUIPMENT } & KITCHEN TAPS \\
\cline { 2 - 6 } \multicolumn{1}{|c|}{} & $\mathbf{1}$ & $\begin{array}{c}\text { TOILETS } \\
\text { Toilet with coupled tank and } \\
\text { dual flush valve }\end{array}$ & $\begin{array}{c}50 \% \text { use taps with motion } \\
\text { detector and } 50 \% \text { taps with } \\
\text { automatic closing }\end{array}$ & $\begin{array}{c}\text { Shower with automatic } \\
\text { closing valve }\end{array}$ & Tap with aerator \\
\cline { 2 - 7 } & $\mathbf{2}$ & $\begin{array}{c}50 \% \text { toilet with coupled tank } \\
\text { and dual flush valve } 50 \% \\
\text { toilet with coupled tank }\end{array}$ & $\begin{array}{c}50 \% \text { use taps with automatic } \\
\text { closing and } 50 \% \text { use taps } \\
\text { with aerator }\end{array}$ & $\begin{array}{c}50 \% \text { use shower with } \\
\text { automatic closing valve and } \\
50 \% \text { use shower with aerator }\end{array}$ & Tap with aerator \\
\cline { 2 - 7 } & $\mathbf{3}$ & $\begin{array}{c}\text { toilet with coupled tank } \\
\text { Tap with aerator }\end{array}$ & Shower with aerator & Tap with aerator \\
\hline
\end{tabular}


Table 1. Values considered for the distribution of water consumption per conventional equipment and reduction per water-saving equipment.

\begin{tabular}{lcc}
\hline \multicolumn{1}{c}{ Scenarios } & DWCi $^{*}$ & Fr $^{* *}$ \\
\hline Six-liter toilet tank & 0.29 & 0.50 \\
Dual flush toilet valve & 0.29 & 0.63 \\
Automatic-closing tap for restroom & 0.06 & 0.20 \\
Motion-detector tap & 0.06 & 0.40 \\
Shower with water flow reducer & 0.28 & 0.20 \\
Shower with automatic closing valve & 0.28 & 0.32 \\
Tap with kitchen aerator & 0.17 & 0.20 \\
\hline
\end{tabular}

*DWCi $=$ distribution of water consumption per sanitary equipment; ${ }^{* *} \mathrm{Fr}=$ factor of reduction of water consumption per water-saving equipment. Source: Guedes, Ribeiro and Vieira (2014).

Where:

EDAi $=$ Water saving provided by the water-saving equipment ( $\left.\mathrm{m}^{3} / \mathrm{month}\right)$;

$\mathrm{CACi}=$ mean monthly consumption of the conventional equipment $\mathrm{i}\left(\mathrm{m}^{3} / \mathrm{month}\right)$;

CAPi $=$ monthly consumption with the implementation of the water-saving equipment $\left(\mathrm{m}^{3} /\right.$ month).

For the calculation of the return of investment (RI), it was considered the saving in the water bill of the user as suggested by Guedes, Ribeiro and Vieira (2014) as well as the initial investment. For the initial investment, in addition to the investment in equipment, it was also considered the expenses for their installation. In other words, compositions of cost per service were developed. For the determination of the time of financial return, the initial investment (cost of equipment and services for installation) was taken into account, subtracted from the volume of water saved multiplied by the water fare. This calculation has been made so many times necessary until the value of the initial investment reaches zero. According to Equations 8 and 9:

$$
R I t=(E D A \times P) t
$$

$$
\boldsymbol{I o}-(\boldsymbol{R I} 1+\boldsymbol{R I} 2+\ldots+\boldsymbol{R I n})=0
$$

Where:

RIt $=$ return of investment in month $\mathrm{t}$;

EDA $=$ water saving $\left(\mathrm{m}^{3} /\right.$ month $)$ provided by the scenario in month t;

$\mathrm{P}=$ value of the water faire $\left(\mathrm{R} \$ / \mathrm{m}^{3}\right)$ in month $\mathrm{t}$;

Io = initial investment for the adoption of the scenario/management measure.

The index of reduction in consumption (IR) was calculated through Equation 10:

$$
\operatorname{IR}(\%)=\frac{\text { Water saving }}{C A C i} \times 100
$$

Where:

Water saving = established according to equation 7;

$\mathrm{CACi}=$ mean monthly consumption of the conventional equipment $\mathrm{i}\left(\mathrm{m}^{3} / \mathrm{month}\right)$.

\section{RESULTS OBTAINED AND DISCUSSIONS}

Figure 2 represents the municipality of Caruaru divided in its 23 neighborhoods. The eight areas selected for the study, by observing the criteria previously described, were the following: Alto do Moura, Boa Vista, Cidade Alta, Indianápolis, Kennedy, Maurício de Nassau, Petrópolis, and Salgado. The neighborhood of Boa Vista, for example, is mainly constituted of old low-income housing developments, such as COHAB I, II and III, and configures popular houses. In turn, Alto do Moura is a tourist district, where the middle/upper class predominates and there are lots of restaurants and craft shops.

From the Censuses conducted by IBGE (2010) available, that is, referent to the years of 1991, 2000, and 2010, the mean rate of growth in the municipality was established as $2.29 \%$ per year, from Equations 2 and 3. Table 2 presents the respective populations estimated for the areas selected in this research.

The following chart (Figure 3 ) indicates the consumption per capita in the neighborhoods for the years of 2010 up to the year of 2015. The information in these charts was obtained through data provided by the water company. The mean volume consumed and the amount of saving values measured were considered every month for each year analyzed.

This graph shows a diversified consumption among the neighborhoods. The lowest mean consumption was recorded for the area of Boa Vista in the year of 2013 (45 L/(person.day)), and the highest also occurred in the year of 2013 in the area of Alto do Moura (320 L/(person.dia)).

It is noticed that there was a decrease in water consumption per capita between the years of 2014 and 2015 in all of the eight areas analyzed. From the data analysis, there was a mean reduction of $23 \mathrm{~L} /$ (person.day), which amounts to around $16 \%$ of the total mean consumption. This event probably occurred because of the management measured taken by the concessionaire, such as the increase in time of water rotation in the areas.

In terms of hydraulic system design, Tsutiya (2006) and Creder (2006) state that the domestic water consumption varies from 150 to $200 \mathrm{~L} /$ (person.day) in residential buildings and houses, and around $120 \mathrm{~L} /$ (person.day) when it comes to popular houses. FUNASA (2015) adopts per capita consumption according to the population of the city or neighborhood where the residence is located, being 100-150 L/(person.day) for residences in regions with a population of up to 6,000 inhabitants, $150-200 \mathrm{~L} /$ (person. day) from 6,000 to 30,000 inhabitants, $200-250 \mathrm{~L} /$ (person.day) from 30,000 to 100,000 inhabitants and 250-300 L/(person. day) for localities with a population greater than one hundred thousand inhabitants.

Therefore, considering the year of 2015, only the neighborhood of Cidade Alta presents consumption values in accordance with what the above-mentioned authors suggest. Alto do Moura exceeds the estimated consumption and the remaining areas are below the suggestions.

Table 3 shows the average consumption of conventional hydrosanitary appliances for the year 2015, by neighborhood. Table 4 shows the average consumption adopting scenario 1 , for the year 2015, also by neighborhood. In the same way, tables were prepared for the year 2035, evaluating the consumption 


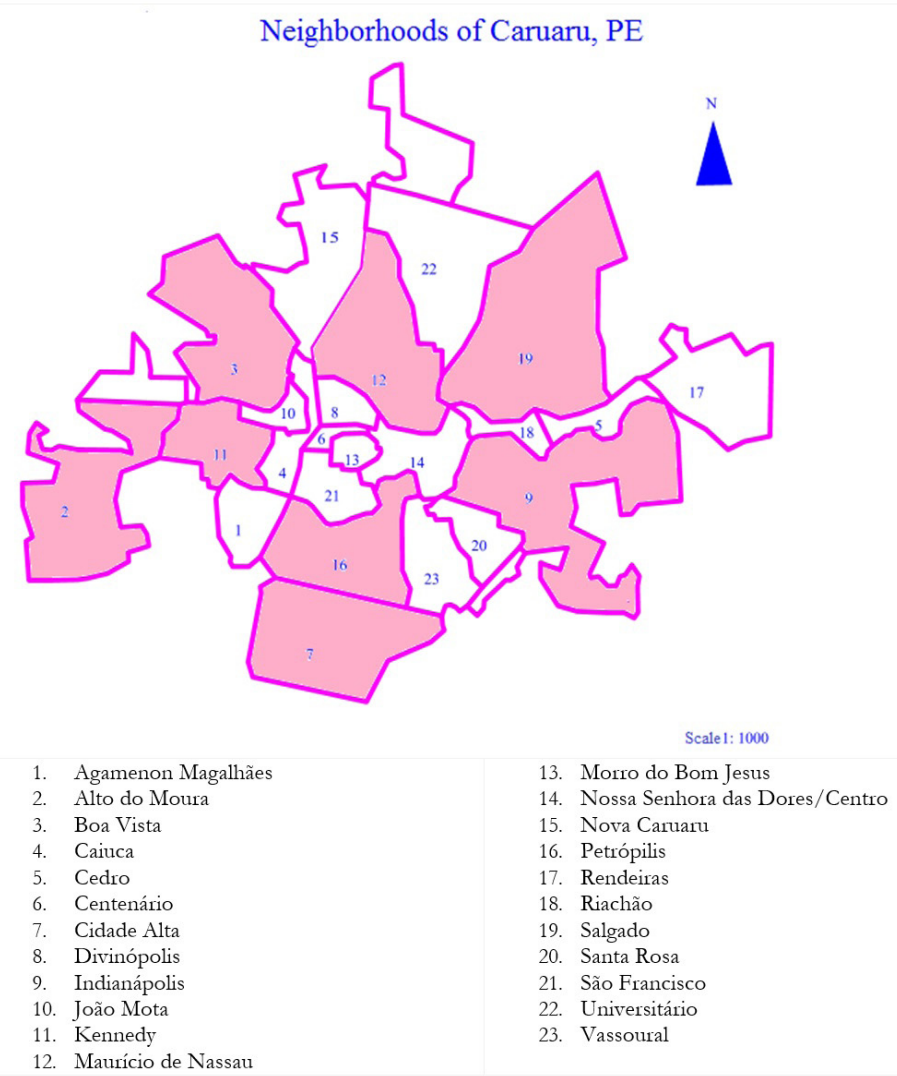

Figure 2. Location of the areas inside the municipality of Caruaru.

Table 2. Populations estimated for 2015 and 2035.

\begin{tabular}{lcc}
\hline Neighborhood & $\begin{array}{c}\text { Estimated } \\
\text { population (2015) }\end{array}$ & $\begin{array}{c}\text { Estimated } \\
\text { population (2035) }\end{array}$ \\
\hline Alto do Moura & 11,103 & 17,463 \\
Boa Vista & 38,884 & 61,187 \\
Cidade Alta & 6,542 & 10,289 \\
Indianápolis & 3,551 & 5,585 \\
Kennedy & 13,491 & 21,218 \\
Maurício de Nassau & 17,398 & 27,363 \\
Petrópolis & 15,967 & 25,112 \\
Salgado & 57,676 & 90,711 \\
\hline
\end{tabular}

of conventional appliances and economizers in each proposed scenario. The results obtained are summarized in Table 5 .

Analyzing the average consumption of the conventional appliances presented in Table 5, for the years 2015 and 2035, it is possible to observe a tendency to an increase in the consumption of around $50 \%$ due to the population growth. It is interesting to emphasize that this value could be even higher considering the suppressed demand, that is, the water that is not consumed due to the lack of offer. Neighborhoods such as Boa Vista, Indianapólis, Kennedy, and Salgado probably consumed more with the offer increase since they present a per capita lower than the indication by Tsutiya (2006), Creder (2006) and FUNASA (2015).

As it is possible to observe that the adoption of scenario 1, that is, the implementation of water-saving equipment with more advanced technology, offers a water saving of around $40 \%$ regarding the volume consumed. Scenario 2, which proposes the installation of equipment with varied technologies, indicates tendencies of $35 \%$ saving. Scenario 3, in turn, which considered the use of water-saving equipment with simpler technologies, presented around $30 \%$ saving.

According to description in the chapter approaching the methodology, for the elaboration of the estimations of costs for the services required for the implementation of the water-saving equipment suggested in this paper, the tables of Price Compositions for Budget (PINI, 2013) were consulted. However, as there are no compositions encompassing the use of water-saving equipment, it was necessary to adapt the hydraulic compositions already existing. Briefly, it is possible to present the values associated with the work, according to Tables 6, 7 and 8, as follows.

The results presented demonstrate that even though the water-saving equipment selected to constitute scenario 1 provide higher water saving values, they demand a higher initial investment. This investment is lower according to the use of lower technologies, as in the case of the results for scenarios 2 and 3. By comparing the results of the price compositions for budgets, it is verified that the investment in scenario 1 is $33 \%$ and $78 \%$ higher than the investment required for scenarios 2 and 3 , respectively.

Table 9 indicated the behavior of the return on invested capital considering the fares of water to be paid. Scenario 1 presented a better performance regarding return time, with an average of six years and six months and a water saving of around $5.7 \mathrm{~m}^{3} / \mathrm{month}$ per residence. In second place, scenario 3 presented an average of seven years and four months of time necessary for the initial 


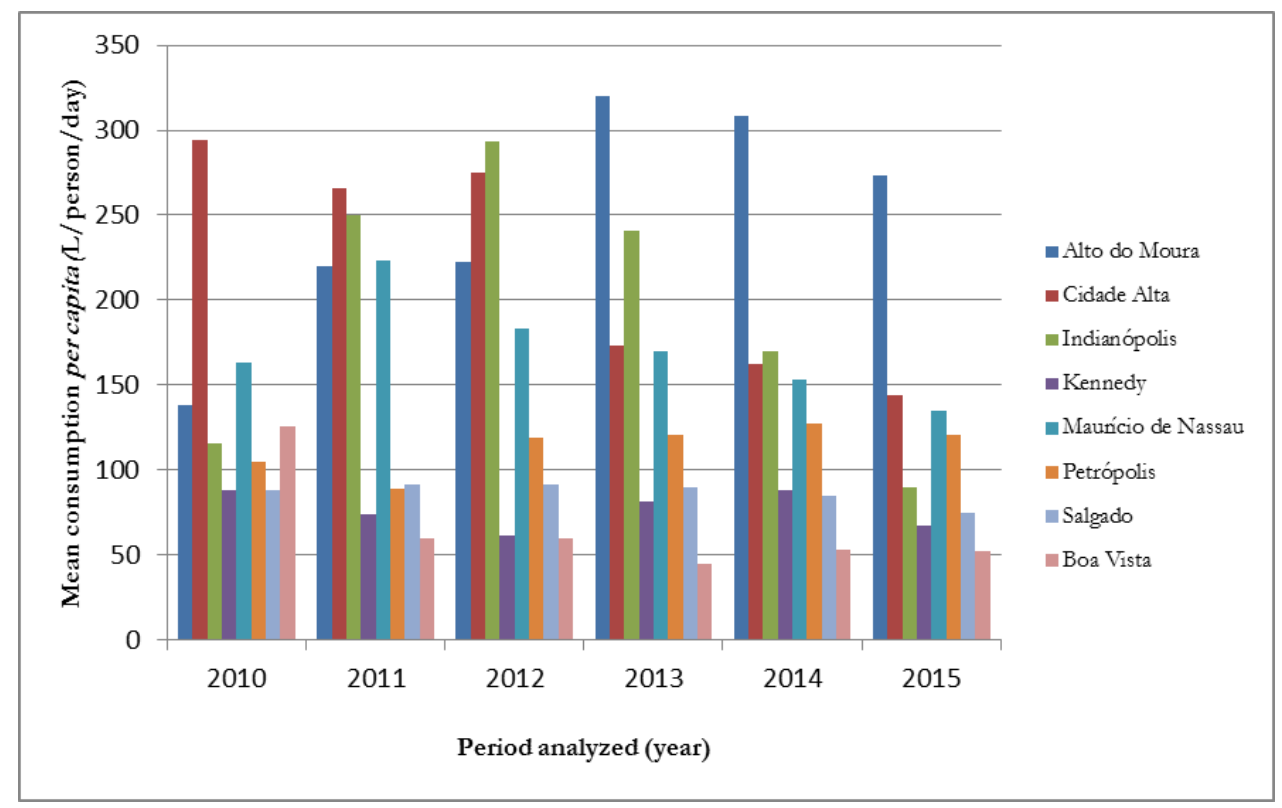

Figure 3. Mean consumption per capita - 2010 to 2015.

Table 3. Mean total consumption of the sanitary equipment per month in each neighborhood along the year of 2015 .

\begin{tabular}{|c|c|c|c|c|c|c|c|c|}
\hline $\begin{array}{l}0 \\
0 \\
0 \\
\frac{1}{0} \\
0 \\
\frac{0}{60} \\
\cdot \frac{0}{0} \\
\mathrm{Z}\end{array}$ & 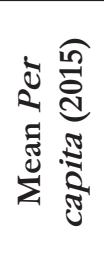 & 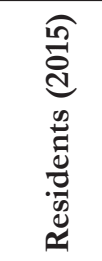 & 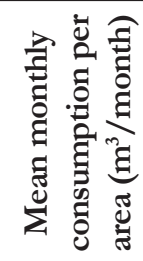 & 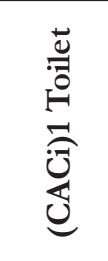 & 옹 & 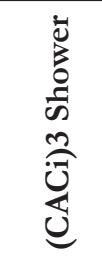 & 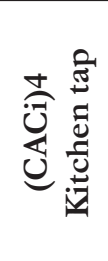 & 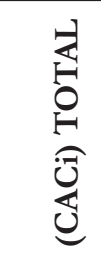 \\
\hline Alto do moura & 273 & 11,103 & 90,933 & 26,370 & 5,456 & 25,461 & 15,458 & 72,746 \\
\hline Boa vista & 52 & 38,884 & 60,659 & 17,591 & 3,639 & 16,984 & 10,312 & 48,527 \\
\hline Cidade Alta & 144 & 6,542 & 28,261 & 8,195 & 1,695 & 7,913 & 4,804 & 22,609 \\
\hline Indianapólis & 90 & 3,551 & 9,587 & 2,780 & 575 & 2,684 & 1,629 & 7,670 \\
\hline Kennedy & 67 & 13,491 & 27,116 & 7,863 & 1,627 & 7,592 & 4,609 & 21,693 \\
\hline Maurício de Nassau & 135 & 17,398 & 70,461 & 20,433 & 4,227 & 19,729 & 11,978 & 56,369 \\
\hline Petropólis & 121 & 15,967 & 57,960 & 16,808 & 3,477 & 16,228 & 9,853 & 46,368 \\
\hline Salgado & 75 & 57,676 & 129,771 & 37,633 & 7,786 & 36,335 & 22,061 & 103,816 \\
\hline TOTAL & & & & & & & & 379,801 \\
\hline
\end{tabular}

Legend: $\mathrm{CACi}=$ Monthly consumption of the conventional equipment $\left(\mathrm{m}^{3} / \mathrm{month}\right)$.

Table 4 . Forecast of water savings, per month, with the installation of saving devices in the year 2015 - (Scenario 1).
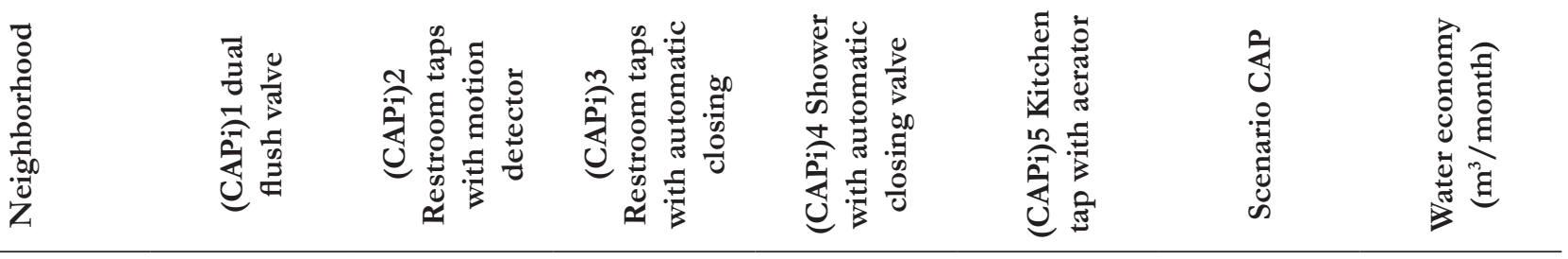

\begin{tabular}{|c|c|c|c|c|c|c|c|}
\hline Alto do Moura & 9,757 & 1,636 & 2,182 & 17,313 & 12,366 & 43,257 & 29,489 \\
\hline Boa Vista & 6,508 & 1,091 & 1,455 & 11,549 & 8,249 & 28,855 & 19,671 \\
\hline Cidade Alta & 3,032 & 509 & 678 & 5,380 & 3,844 & 13,443 & 9,165 \\
\hline Indianapólis & 1,028 & 173 & 230 & 1,825 & 1,304 & 4,560 & 3,109 \\
\hline Kennedy & 6,291 & 488 & 651 & 5,163 & 3,688 & 16,280 & 5,412 \\
\hline Maurício de Nassau & 7,560 & 1,268 & 1,691 & 13,415 & 9,583 & 33,518 & 22,850 \\
\hline Petropólis & 6,219 & 1,043 & 1,391 & 11,035 & 7,883 & 27,571 & 18,796 \\
\hline TOTAL & & & & & & & 150.581 \\
\hline
\end{tabular}

$\mathrm{CAPi}=$ Average monthly consumption of each economizer equipment $\left(\mathrm{m}^{3} / \mathrm{month}\right)$. 
Table 5. Summary considering the total mean consumption of the sanitary equipment per month in each area as well as the conventional equipment and the installation of water-saving equipment along the years of 2015. and 2035.

\begin{tabular}{|c|c|c|c|c|}
\hline \multirow{2}{*}{ Year } & \multirow{2}{*}{$\begin{array}{c}\text { Mean consumption of conventional } \\
\text { equipment }\left(\mathrm{m}^{3} / \text { month }\right)\end{array}$} & \multicolumn{3}{|c|}{ Water-saving equipment $\left(\mathrm{m}^{3} /\right.$ month) } \\
\hline & & Scenario 1 & Scenario 2 & Scenario 3 \\
\hline 2015 & 379,801 & 150,581 & 131,035 & 113,332 \\
\hline 2035 & 597,381 & 236,845 & 206,109 & 178,257 \\
\hline
\end{tabular}

Table 6. Costs associated with the implementation of scenario 1 proposed per residence.

\begin{tabular}{lcc}
\hline \multicolumn{1}{c}{ Scenario 1 } & Item & Cost (R\$) \\
\hline Acquisition and installation of toilet with dual flush valve & 525.17 \\
Acquisition and installation of tap with motion detector or acquisition and installation of tap with automatic closing & 332.45 & 502.51 \\
Acquisition and installation of shower with automatic closing valve & 126.69 & $\mathbf{1 , 4 8 6 . 8 2}$ \\
Acquisition and installation of kitchen tap with aerator & \\
Total &
\end{tabular}

Table 7. Costs associated with the implementation of scenario 2 proposed per residence.

\begin{tabular}{lcc}
\hline \multicolumn{1}{c}{ Scenario 2 } & Cost (R\$) \\
\hline Acquisition and installation of toilet with dual flush valve or acquisition and installation of toilet with conventional coupled tank & 488.78 \\
Acquisition and installation of tap with automatic closing or acquisition and installation of tap with aerator & 183.95 & 314.83 \\
Acquisition and installation of shower with automatic closing valve or acquisition and installation of shower with water-flow reducer & 126.69 \\
Acquisition and installation of kitchen tap with aerator & $\mathbf{1 , 1 1 4 . 2 5}$ & \\
Total &
\end{tabular}

Table 8. Costs associated with the implementation of scenario 3 proposed per residence.

\begin{tabular}{lc}
\hline \multicolumn{1}{c}{ Scenario 3 } & Cost (R\$) \\
\hline $\begin{array}{l}\text { Item } \\
\text { Acquisition and installation of toilet with }\end{array}$ & 452.39 \\
$\begin{array}{l}\text { Acquisition and installation of tap with aerator } \\
\text { Acquisition and installation of shower with }\end{array}$ & 126.69 \\
water-flow reducer & 127.15 \\
$\begin{array}{l}\text { Acquisition and installation of kitchen tap with } \\
\text { aerator }\end{array}$ & 126.69 \\
Total & $\mathbf{8 3 2 . 9 2}$ \\
\hline
\end{tabular}

investment return. However, for this scenario, it was found a very low mean water saving of $2.85 \mathrm{~m}^{3} /$ month. The situation proposed that proved the least interesting frame was scenario 2 , since its return time proved longer than the remaining ones, around eight years and seven months for a monthly water saving per residence of $3.1 \mathrm{~m}^{3} /$ month.

Considering the lower fare practiced by the water and sewage concessionaire responsible for the municipality, within scenario 1 , each residence would have a monthly water saving from $R \$ 24.34$.

\section{CONSIDERATIONS}

Despite the existence of ongoing projects and constructions structuring sanitation such as, respectively, the Adutora de Serro Azul and the Adutora do Agreste, aiming at the improvement of water public supply for the population of Caruaru, it is necessary to consider that the population will continue to grow, according
Table 9. Return time for the scenarios.

\begin{tabular}{|c|c|c|c|c|}
\hline \multirow[b]{2}{*}{ Scenario } & \multirow{2}{*}{$\begin{array}{c}\text { Initial } \\
\text { investment } \\
(\mathrm{R} \$)\end{array}$} & \multicolumn{2}{|c|}{ Monthly savings } & \multirow{2}{*}{$\begin{array}{c}\text { Mean } \\
\text { financial } \\
\text { return time }\end{array}$} \\
\hline & & $\mathrm{m}^{3}$ & $\mathbf{R} \$$ & \\
\hline 1 & $1,486.82$ & 5.7 & 24.34 & $\begin{array}{c}6 \text { years and six } \\
\text { months }\end{array}$ \\
\hline 2 & $1,114.25$ & 3.2 & 13.67 & $\begin{array}{c}8 \text { years and } 7 \\
\text { months }\end{array}$ \\
\hline 3 & 832.92 & 2.8 & 11.96 & $\begin{array}{c}6 \text { years and } 9 \\
\text { months }\end{array}$ \\
\hline
\end{tabular}

to tendencies in population studies that have been carried out. Therefore, it is necessary that in addition to searching for water in sources more distant from the point to be supplied, conservation actions have to be considered as instruments to support urban water management.

Considering the implementation of scenario 1 in the 23 neighborhood of the municipality, in the year of 2015, it would be necessary an investment of around $\mathrm{R} \$ 132$ million. As a suggestion and taking as basis the Conservation Planning from other countries, it would be interesting for the government to fund roughly $30 \%$ of the investment in each residence as incentive to the adoption of the action proposed. Therefore, the investment by the government would be of $\mathrm{R} \$ 40$ million. As it is probable that the action extends along a period of around 48 months, the annual disbursement would be roughly $\mathrm{R} \$ 10$ million.

Scenario 1, despite the higher initial investment, presented the best return time. The mean monthly water volume that would be saved in the year of 2015 with the implementation of scenario 1 in all of the residences in the municipality is around $506,300 \mathrm{~m}^{3}$ / month. Considering the mean per capita of the eight areas analyzed, 
that is, $120 \mathrm{~L} /$ (person.day), it would be possible to supply around forty-two thousand residences with water saved.

For all the scenarios analyzed, the time of return of the initial costs could be reduced if the tariff values applied by the water utility were readjusted.

According to the local concessionaire, Caruaru has $45 \%$ of the municipality with collection and treatment of sewage. Thus, considering a residence attended by the conventional sewage treatment system, scenario 1 would present a mean return time of three years and minimum return time of a little more than one year.

This study did not account values associated with possible civil interventions in the residences, which may charge the initial investment. In contrast, this study did not consider the adaptation of conventional equipment existing into water-saving equipment either, which may reduce the initial cost.

The results presented lead to the conclusion that the incentive to the installation of water-saving equipment in residences is a viable and interesting measure considering the water management of a municipality. In case of the implementation of a water conservation planning in residences in the municipality of Caruaru, this action proves a relevant impact and should be considered.

\section{REFERENCES}

ABICALIL, M. T. O impacto das mudanças climáticas em empresas de água e saneamento no Brasil. São Paulo: ABES, 2014. 34 slides, color. Available from: <http://www.abes-dn.org.br/eventos/XIISIBESA/ Painel/P1A.pdf>. Access on: 29 mar. 2016.

BRAGA, C. F. C.; RIBEIRO, M. M. R. Experiências em Gerenciamento da demanda urbana de água. In: CONGRESSO BRASILEIRO DE ENGENHARIA SANITÁRIA E AMBIENTAL, 21., 2001, João Pessoa. Anais... Rio de Janeiro: Associação Brasileira de Engenharia Sanitária e Ambiental, 2001. Available from: <http:// www.bvsde.paho.org/bvsaidis/saneab/brasil/iv-036.pdf>. Access on: 23 apr. 2016.

CAHILL, R.; LUND, J. Residential water conservation in Australia and California. Journal of Water Resources Planning and Management, v. 139, n. 1, 2012.

CEF - CAIXA ECONÔMICA FEDERAL. SINAPI - SISTEMA NACIONAL DE PESQUISA DE CUSTOS E ÍNDICES DA CONSTRUÇÃO CIVIL. Tabelas base novembro/2016. Brasília, 2016.

CREDER, H. Instalações hidráulicas e sanitárias. 6. ed. Rio de Janeiro: Ed. LTC - Livros Técnicos e Científicos, 2006. 465 p.

EEA - EUROPEAN ENVIRONMENT AGENCY. Urban sustainability issues - resource-efficient cities: good practice. Denmark, 2015. (EEA Technical report, 24/2015).

FUNASA - FUNDAÇÃO NACIONAL DE SAÚDE. Manual de saneamento. 4. ed. Brasília, 2015.

GUEDES, M. J. F.; RIBEIRO, M. M. R.; VIEIRA, Z. M. C. Alternativas de gerenciamento de água na escala de uma cidade.
Revista Brasileira de Recursos Hídricos, v. 9, n. 2, p. 123-134, 2014. http://dx.doi.org/10.21168/rbrh.v19n2.p123-134.

HAQUE, M. M.; EGODAWATTA, P.; RAHMAN, A.; GOONETILLEKE, A. Assessing the significance of climate and community factors on urban water demand. International Journal of Sustainable Built Environment., v. 4, n. 2, p. 222-230, 2015. http:// dx.doi.org/10.1016/j.ijsbe.2015.11.001.

IBGE - INSTITUTO BRASILEIRO DE GEOGRAFIA E ESTATÍSTICA.Cidades@: dados populacionais e sociais, referentes ao CENSO 2010. Rio de Janeiro, 2010. Available from: <http:// cod.ibge.gov.br/ZU0>. Access on: 26 june 2016.

IMTEAZ, M. A.; ADEBOYE, O. B.; RAYBURG, S.; SHANABLEH, A. Rainwater harvesting potential for southwest Nigeria using daily water balance model. Resources, Conservation and Recycling, v. 62, p. 51-55, 2012. http://dx.doi.org/10.1016/j.resconrec.2012.02.007.

LACERDA, F. F. Tendências de temperatura e precipitação e cenários de mudanças climáticas de longo prazo no nordeste do brasil e em ilhas oceânicas. 2015. 114 f. Tese (Doutorado em Engenharia Civil) - Departamento de Engenharia Civil, Universidade Federal de Pernambuco, Recife, 2015.

LEUCK, M. F. Avaliação Econômica do impacto de medidas individualizadas de conservação de água em Porto Alegre. 2008. 158 f. Dissertação (Mestrado em Recursos Hídricos e Saneamento Ambiental) - Programa de Pós-graduação em Recursos Hídricos e Saneamento Ambiental, Universidade Federal do Rio Grande do Sul, Porto Alegre, 2008.

MINI, C.; HOGUE, T. S.; PINCETL, S. The effectiveness of water conservation measures on summer residential water in Los Angeles, California. Resources, Conservation and Recycling, v. 94, p. 136145, 2015. http://dx.doi.org/10.1016/j.resconrec.2014.10.005.

PINI. Tabelas de composições de preço - TCPO 14. São Paulo, 2013

RATH, R. C.; ACHARYA, P.; NAYAK, P.; SWAIN, S. Roof water preservation system and its consumption in Bhubaneswar city: emerging needs and challenges. International Journal of Scientific Research, v. 5, n. 12, 2016.

REGION OF WATERLOO WATER SERVICES. Sustaining our water supply: water efficiency master plan (2015-2025). Kitchener, Ontario, 2014.

SABESP - COMPANHIA DE SANEAMENTO BÁSICO DO ESTADO DE SÃO PAULO. CHESS - crise hidrica, estratégia e soluç̃es da SABESP. São Paulo, 2015. Available from: <http:// site. sabesp.com.br/site/uploads/file/crisehidrica/chess_crise_hidrica. pdf $>$. Access on: 10 jan. 2017.

SINGH, L. K.; JHA, M. K.; CHOWDAYRY, V. M. Multi-criteria analysis and GIS modeling for identifying prospective water harvesting and artificial recharge sites for sustainable water supply. Journal of Cleaner Production, v. 142, p. 1436-1456, 2016. http:// dx.doi.org/10.1016/j.jclepro.2016.11.163. 
SUDENE - SUPERINTENDÊNCIA DO DESENVOLVIMENTO DO NORDESTE. Nordeste em números 2011: estatística do Nordeste. Recife: SUDENE, 2013. 283 p.

TSUTIYA, M. T. Abastecimento de água. 3. ed. São Paulo: Escola Politécnica da USP, 2006.

\section{Authors contributions}

Juliana Karla da Silva: contributed to the bibliographic research, characterization of the study area, data collection, treatment and analysis, elaboration of the methodology and development of the model, discussion of the results and elaboration of the text.

Luiz Gustavo Costa Ferreira Nunes: contributed to the bibliographic research, elaboration of the methodology, discussion of the results and elaboration of the text.

Anna Elis Paz Soares: contributed to the bibliographic research, elaboration of the methodology, discussion of the results and elaboration of the text.

Simone Rosa da Silva: contributed to the orientation and conception of the work, discussion of the results and elaboration of the text. 